\title{
Chebulagic acid inhibits the LPS-induced expression of TNF- $\alpha$ and IL-1 $\beta$ in endothelial cells by suppressing MAPK activation
}

\author{
YUEYING LIU, LUER BAO, LIYING XUAN, BAOHUA SONG, LIN LIN and HAO HAN \\ Teaching and Research Section of Physiology and Pathophysiology, Medical College, \\ Inner Mongolia University for the Nationalities, Tongliao, Inner Mongolia 028041, P.R. China
}

Received July 31, 2014; Accepted April 13, 2015

DOI: $10.3892 /$ etm.2015.2447

\begin{abstract}
Inflammatory response in the vasculature, including the overexpression of tumor necrosis factor (TNF)- $\alpha$ and interleukin (IL)-1 $\beta$, has been demonstrated to increase the risk of thrombosis development. Chebulagic acid (CA) is a key chemical component in the traditional Mongolian anti-thrombotic drug Garidi-13, and has been suggested to exert anti-inflammatory and anti-infective effects. The present study aimed to evaluate the regulatory impact of CA on a number of biological processes, including lipopolysaccharide (LPS)-induced inflammation, LPS-promoted mitogen-activated protein kinase (MAPK) activation and the expression of toll-like receptor (TLR)4 in EA.hy926 human endothelial cells. The results indicated that CA significantly inhibited the LPS-induced upregulation of TNF- $\alpha$ and IL-1 $\beta$ in a dose- and time-dependent manner. Furthermore, LPS-activated MAPK signaling was inhibited by CA treatment in the EA.hy926 cells. However, TLR4, which serves a key function in LPS-induced inflammation as the receptor of LPS, was not regulated by the CA treatment. In summary, the results of the present study indicate that $\mathrm{CA}$ inhibits the LPS-induced promotion of TNF- $\alpha$ and IL- $1 \beta$ in endothelial cells by suppressing MAPK activation, which may contribute to the anti-thrombotic effect of Garidi-13.
\end{abstract}

\section{Introduction}

Thrombosis is a pathogenically complex condition with multiple risk factors, of which infection and vascular inflammation are crucial $(1,2)$. Various cytokines have been demonstrated to influence thrombogenesis, such as tumor necrosis factor (TNF)- $\alpha$ and interleukin (IL)-6,

Correspondence to: Dr Yueying Liu, Teaching and Research Section of Physiology and Pathophysiology, Medical College, Inner Mongolia University for the Nationalities, 996 Xilamulun Street, Tongliao, Inner Mongolia 028041, P.R. China

E-mail: yueyimun@163.com

Key words: chebulagic acid, tumor necrosis factor- $\alpha$, interleukin-1 $\beta$, endothelial cells which are primarily secreted by activated monocytes and macrophages (3). Inflammation-induced TNF- $\alpha$ and IL-6 subsequently stimulate vascular endothelial cells to become prothrombotic and exhibit anticoagulant properties to various extents. Prothrombotic vascular endothelial cells then express chemokines and E-selectin, which facilitate thromobogenesis by increasing the ability of platelets to adhere to vascular thrombosis sites via interaction with CX3CL1 or E-selectin $(4,5)$, or the induction of platelet aggregation involving chemokine (C-C motif) ligand 5 (6,7). Furthermore, cytokines are known to stimulate the secretion of tissue factor from monocytes, macrophages and endothelial cells (via TNF- $\alpha$ ) $(8,9)$, and to induce the expression of plasminogen activator inhibitor-1 and C-reactive protein in the liver (10-13). In addition, TNF- $\alpha$ and IL-6 have been demonstrated to increase the risk of thrombosis development by stimulating the secretion and inhibiting the cleavage of ultralarge Von Willebrand multimers (14). Upregulated proinflammatory cytokines in macrophages and endothelial cells further promote the dysfunction of the endothelium $(15,16)$, forming a positive feedback signal. Intravascular thrombosis is a well-recognized complication of vascular inflammation. Thus, anti-inflammatory intervention in the vasculature, particularly the vascular endothelium, may be an effective strategy for the prevention or mitigation of thrombosis.

Chebulagic acid (CA) is a key chemical component of the traditional Mongolian anti-thrombotic drug Garidi-13 (17). The anti-infective and the anti-inflammatory effects of CA have been recognized. CA has been demonstrated to limit herpes simplex virus (HSV) infection by targeting viral glycoproteins and inhibiting HSV-1 entry and cell-to-cell transmission (18). HSV infection has been confirmed to be involved in the pathogenesis of atherosclerosis and thrombosis (19-22). Furthermore, the anti-inflammatory effects of CA have been observed to inhibit the activity of cyclooxygenase, a key thrombosis promoter (23-26). In addition, CA has been demonstrated to attenuate lipopolysaccharide (LPS)-induced inflammation by suppressing nuclear factor $(\mathrm{NF})-\kappa \mathrm{B}$ and mitogen-activated protein kinase (MAPK) activation in macrophages (27). Therefore, the anti-inflammatory effects of CA may be the basis of its anti-thrombotic potential, and thus require further study.

In the present study, the ability of CA to inhibit LPS-induced vascular inflammation was investigated by measuring the 
levels of IL-1 $\beta$ and TNF- $\alpha$ in EA.hy926 human endothelial cells. The underlying mechanism was also investigated.

\section{Materials and methods}

Reagents and cell cultures. Escherichia coli LPS and CA were purchased from Sigma-Aldrich (St. Louis, MO, USA) and were resolved in RPMI-1640 medium (Invitrogen Life Technologies, Carlsbad, CA, USA) supplemented with $2 \%$ fetal bovine serum (FBS). EA.hy926 human endothelial cells were obtained from the American Type Culture Collection (Rockville, MD, USA). EA.hy926 cells were propagated in RPMI-1640 medium supplemented with 10\% FBS (Gibco Life Technologies, Rockville, MD, USA) at $37^{\circ} \mathrm{C}$ under $5 \% \mathrm{CO}_{2}$, or maintained in RPMI-1640 medium supplemented with $2 \%$ FBS. EA.hy926 cells at $~ 85 \%$ confluence were treated with $0,10,100$ or $1,000 \mathrm{ng} / \mathrm{ml}$ LPS and/or with 0,10 or $50 \mu \mathrm{M}$ CA for $0,3,6$ or $12 \mathrm{~h}$. Cells were subsequently lysed for mRNA and protein expression analysis. For the TNF- $\alpha$ and IL-1 $\beta$ assays, the supernatant of the LPS- and/or CA-treated EA.hy926 cells was collected and centrifuged at for $15 \mathrm{~min}$ at $4^{\circ} \mathrm{C}$ and $13,200 \mathrm{x}$. The supernatant was then transferred to new tubes and stored at $-20^{\circ} \mathrm{C}$ until required for assays.

ELISA assay for IL-1 $\beta$ or TNF- $\alpha$. For the determination of the expression levels of IL- $1 \beta$ and TNF- $\alpha$, the supernatants of the LPS- and/or CA-treated EA.hy926 cells were analyzed using an human IL-1 $\beta$ or TNF- $\alpha$ ELISA kit (Shanghai ExCell Biology Inc., Shanghai, China) according to the manufacturer's instructions. In brief, standards and samples were diluted with phosphate-buffered saline (PBS), loaded onto a 96-well plate and incubated for $90 \mathrm{~min}$ at $37^{\circ} \mathrm{C}$. Next, biotin-labeled antibodies against IL- $1 \beta$ or TNF- $\alpha$ were utilized for specific binding. Finally, an avidin-labeled enzyme and substrate were used to quantitatively examine the levels of IL- $1 \beta$ and TNF- $\alpha$ using a spectrophotometer (Bio-Rad Laboratories, Inc., Hercules, CA, USA).

Western blot analysis. EA.hy926 endothelial cells post treatment were treated with ice-cold cell lysis reagent (Sigma-Aldrich) according to the manufacturer's instructions, and each protein sample was supplemented with protease inhibitor cocktail (Roche Diagnostics, Basel, Switzerland), then quantified by bicinchoninic acid assay (Pierce Biotechnology, Inc., Rockford, IL, USA). Protein samples were separated using SDS-PAGE (10-12\%) and detected by western blot analysis using polyclonal rabbit antibodies against p38, phosphorylated p38 (\#sc-535, 1:500), c-Jun N-terminal kinase (JNK; \#sc-571, 1:400), phosphorylated JNK (\#sc-135642, 1:200), extracellular signal-regulated kinase (ERK), phosphorylated ERK (\#sc-23759-R, 1:200), TLR4 (\#sc-10741, 1:200) and $\beta$-actin (\#sc-130656, 1:1,000; Santa Cruz Biotechnology, Inc., Dallas, TX, USA). Horseradish peroxidase-conjugated goat anti-rabbit IgG secondary antibodies (Pierce) and an electrochemiluminescence detection system (Amersham Pharmacia Biotech, Amersham, UK) were used for detection.

$m R N A$ extraction and reverse transcription-quantitative polymerase chain reaction ( $R T-q P C R)$ analysis. Total mRNA was extracted from cell samples using an RNeasy Mini kit
(Qiagen, Inc., Valencia, CA, USA) according to the manufacturer's instructions, and supplemented with RNase inhibitor (Takara Bio, Inc., Tokyo, Japan). RT-qPCR analysis of the TLR4 mRNA level was performed using a QuantiTect SYBR Green PCR kit (Qiagen, Inc.). All mRNA expression levels were normalized against $\beta$-actin. The $2^{-\Delta \Delta \mathrm{Ct}}$ method was used for the relative quantification of TLR4 mRNA expression (28).

Statistical analysis. Data are presented as the mean \pm standard error, and were analyzed using Student's t-test. $\mathrm{P}<0.05$ was considered to indicate a statistically significant difference. All tests were performed using GraphPad Prism 6 software (GraphPad Software, Inc., La Jolla, CA, USA).

\section{Results}

CA inhibits the LPS-induced secretion of IL-1 $\beta$ and TNF- $\alpha$ in endothelial cells. In order to determine whether CA inhibits the LPS-induced secretion of IL-1 $\beta$ and TNF- $\alpha$, EA.hy 926 endothelial cells were treated with LPS $(10,100$ or $1,000 \mathrm{ng} / \mathrm{ml})$ and/or CA $(0,10$ or $50 \mu \mathrm{M})$ for $12 \mathrm{~h}$. Subsequently, the IL-1 $\beta$ and TNF- $\alpha$ content in the cell supernatant was determined using an ELISA assay. Firstly, it was demonstrated that the LPS treatment significantly promoted the expression of IL-1 $\beta$ and TNF- $\alpha$ in the cell supernatant. Treatment with $10 \mathrm{ng} / \mathrm{ml}$ LPS induced a 5.8-fold elevation in the levels of IL-1 $\beta$ and a 19-fold elevation of TNF- $\alpha$ levels in the EA.hy926 cells $(\mathrm{P}<0.01$ and $\mathrm{P}<0.001$, respectively; Fig. $1 \mathrm{~A}$ and $\mathrm{B}$ ). The promotion of IL-1 $\beta$ and TNF- $\alpha$ secretion was dose-dependent; significant difference in the levels of IL- $1 \beta$ and TNF- $\alpha$ were observed between the 10 and 100 or $1,000 \mathrm{ng} / \mathrm{ml}$ groups, as follows: 10 vs. $100 \mathrm{ng} / \mathrm{ml}(\mathrm{P}<0.01)$ and 100 vs. 1,000 ng/ml $(\mathrm{P}<0.05)$ for IL-1 $\beta$; 10 vs. $100 \mathrm{ng} / \mathrm{ml}$ and 100 vs. $1,000 \mathrm{ng} / \mathrm{ml}(\mathrm{P}<0.01)$ for TNF- $\alpha$. Secondly, the induction of IL-1 $\beta$ and TNF- $\alpha$ in EA.hy926 cells was reexamined following combined treatment with LPS and CA. CA was observed to significantly attenuate the LPS-induced increase in the expression of IL-1 $\beta$ and TNF- $\alpha$ (Fig. 1C and D). Reduced levels of IL-1 $\beta$ or TNF- $\alpha$ were observed in EA.hy926 cells treated with a combination of $1 \mu \mathrm{g} / \mathrm{ml}$ LPS and 10 or $50 \mu \mathrm{M}$ CA compared with the levels in EA.hy926 cells treated with $1 \mu \mathrm{g} / \mathrm{ml}$ LPS only $(\mathrm{P}<0.01$ and $\mathrm{P}<0.001$, respectively, for IL-1 $\beta ; \mathrm{P}<0.05$ and $\mathrm{P}<0.01$, respectively, for TNF- $\alpha$ ). This attenuation was dose-dependent, as the LPS-induced levels of IL-1 $\beta$ and TNF- $\alpha$ in the cells treated with $50 \mu \mathrm{M}$ CA were observed to be lower than those in the cells treated with $10 \mu \mathrm{M} \mathrm{CA}$. Notably, the inhibition of IL-1 $\beta$ or TNF- $\alpha$ expression by CA was not significant in the EA.hy926 cells that were not treated with LPS, possibly as the background secretion of cytokines was insufficient to discriminate the inhibitory effect of CA.

In order to further investigate the CA-mediated inhibition of proinflammatory cytokines in endothelial cells, the levels of IL-1 $\beta$ and TNF- $\alpha$ were determined in the supernatants of EA.hy926 cells at various periods following treatment with $1 \mu \mathrm{g} / \mathrm{ml}$ LPS and/or with $50 \mu \mathrm{M}$ CA. As presented in Fig. 2A, the inhibitory effect of CA on IL-1 $\beta$ secretion was significant at $3 \mathrm{~h}$ post-treatment. The levels of IL-1 $\beta$ were found to be reduced in cells treated with a combination of $50 \mu \mathrm{M} \mathrm{CA}$ and $1 \mu \mathrm{g} / \mathrm{ml}$ LPS compared with those in the cells treated with LPS alone $(\mathrm{P}<0.05)$, and the inhibitory effect was greater at 6 or $12 \mathrm{~h}$ 
A

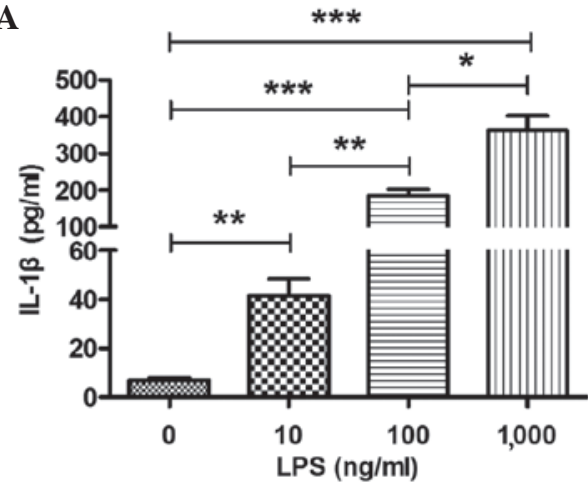

C

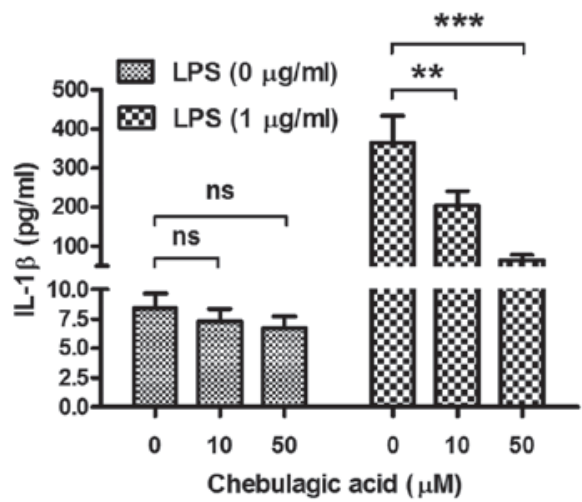

B
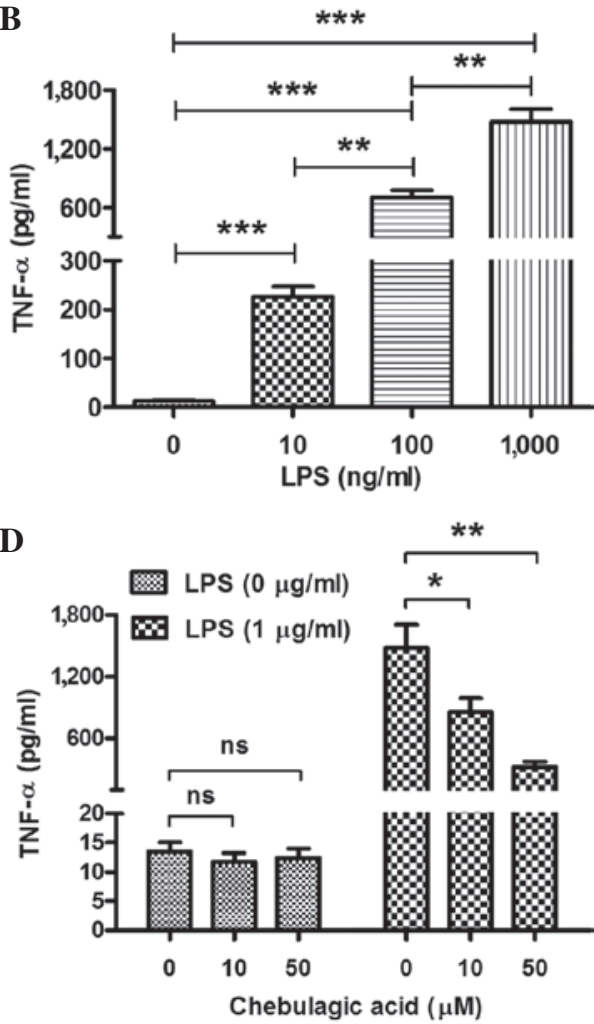

Figure 1. Chebulagic acid dose-dependently inhibits LPS-mediated IL-1 $\beta$ and TNF- $\alpha$ upregulation in EA.hy 926 cells. LPS upregulates (A) IL-1 $\beta$ and (B) TNF- $\alpha$ expression in EA.hy926 cells dose-dependently. Chebulagic acid inhibits the LPS-mediated upregulation of (C) IL-1 $\beta$ and (D) TNF- $\alpha$ dose-dependently. All experiments were performed in triplicate. ${ }^{*} \mathrm{P}<0.05,{ }^{* * *} \mathrm{P}<0.01$ and ${ }^{* * * *} \mathrm{P}<0.001$. IL-1 $\beta$, interleukin-1 $\beta$; LPS, lipopolysaccharide; TNF- $\alpha$, tumor necrosis factor- $\alpha$; ns, no significance.
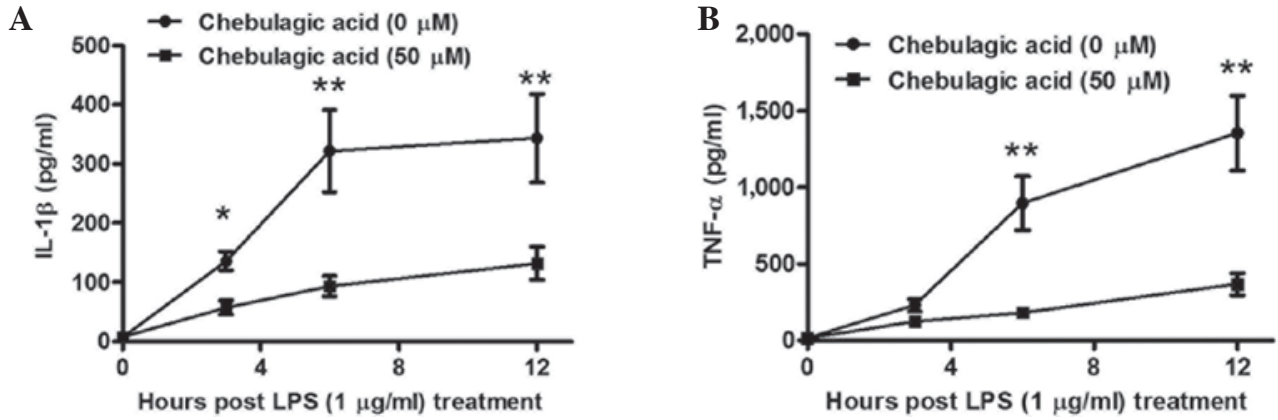

Figure 2. Chebulagic acid time-dependently inhibits LPS-mediated IL-1 $\beta$ and TNF- $\alpha$ upregulation in EA.hy926 cells. Treatment with $50 \mu$ M chebulagic acid time-dependently attenuated (A) IL-1 $\beta$ and (B) TNF- $\alpha$ upregulation in LPS-treated EA.hy926 cells. All results are the mean of three independent experiments. ${ }^{*} \mathrm{P}<0.05$ and ${ }^{* *} \mathrm{P}<0.01$ vs. the $50 \mu \mathrm{M}$ group. IL-1 $\beta$, interleukin-1 $\beta$; LPS, lipopolysaccharide; TNF- $\alpha$, tumor necrosis factor- $\alpha$.

post-treatment $(\mathrm{P}<0.01)$. Furthermore, the inhibitory effect of TNF- $\alpha$ secretion was initially observed at $6 \mathrm{~h}$ post-treatment $(\mathrm{P}<0.01)$, then reconfirmed at $12 \mathrm{~h}$ post-treatment $(\mathrm{P}<0.01)$. Therefore, the results indicate that the $\mathrm{CA}$-mediated inhibition of proinflammatory cytokines in the endothelial cells was time-dependent.

CA inhibits the LPS-induced activation of MAPK signaling in endothelial cells. In order to investigate how CA affected the secretion or expression of IL- $1 \beta$ or TNF- $\alpha$, the degree of activation of MAPK signaling in the LPS- and/or CA-treated EA.hy926 cells was analyzed, as MAPK signaling is known to be promoted by LPS and to upregulate proinflammatory cytokines $(29,30)$. Western blot analysis was performed to examine the expression and phosphorylation of p38, JNK and ERK in EA.hy926 cells following various treatments. Fig. 3 indicates that levels of phosphorylated p38, JNK and ERK were significantly elevated as a result of treatment with $1 \mu \mathrm{g} / \mathrm{ml}$ LPS for $12 \mathrm{~h}(\mathrm{P}<0.01)$. However, this promoted phosphorylation of $\mathrm{p} 38$, JNK and ERK was significantly attenuated by treatment with $50 \mu \mathrm{M}$ CA $(\mathrm{P}<0.01)$, with JNK phosphorylation detectably attenuated by $10 \mu \mathrm{M} \mathrm{CA}(\mathrm{P}<0.05)$. Furthermore, the attenuation was dose-dependent, as a significant difference was detected between the $10 \mu \mathrm{M}$ - and $50 \mu \mathrm{M}$-treated cells ( $\mathrm{P}<0.01$ for $\mathrm{p} 38$ or JNK phosphorylation; $\mathrm{P}<0.05$ for ERK phosphorylation). Therefore, the results indicate that CA treatment attenuated MAPK activation in the LPS-induced inflammatory cells. 

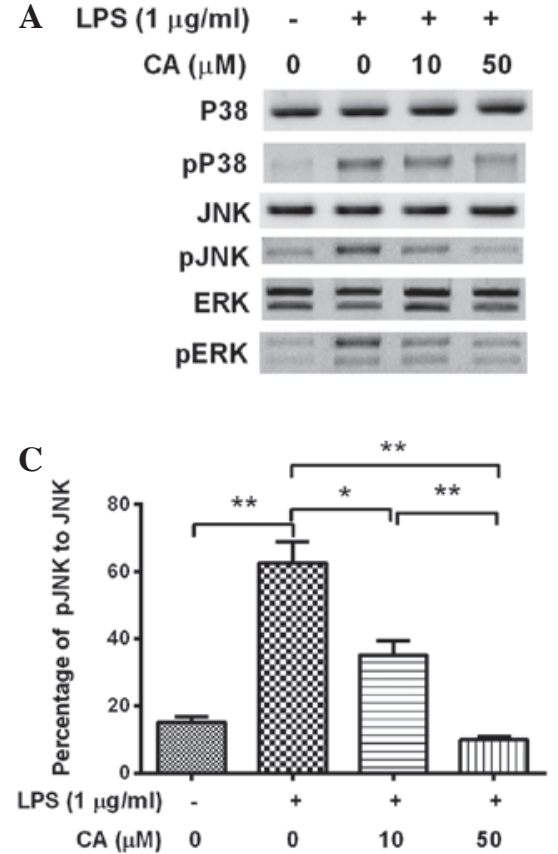

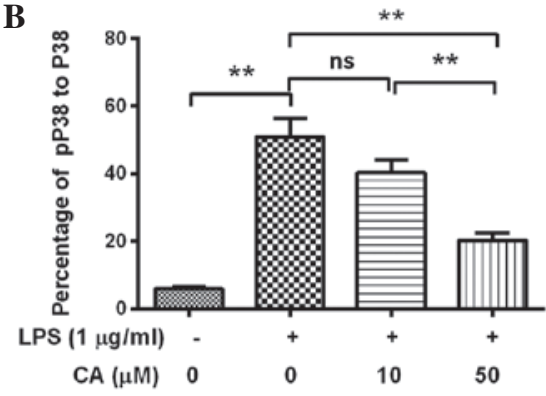

D

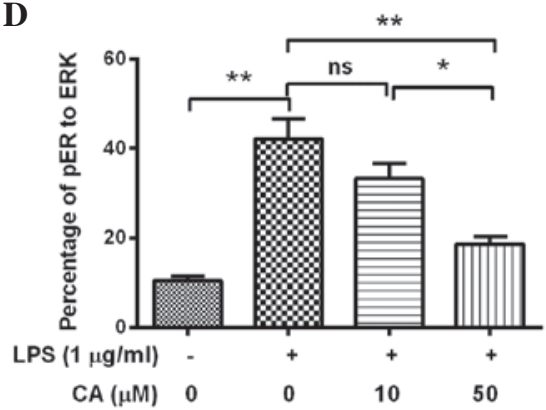

Figure 3. Effect of CA on the activation of mitogen-activated protein kinase signaling in LPS-stimulated EA.hy926 cells. (A) Western blot analysis of p38, JNK and ERK with or without phosphorylation in CA- and LPS-treated EA.hy926 cells. Percentage of phosphorylated to unphosphorylated (B) p38, (C) JNK and (D) ERK in CA- and LPS-treated EA.hy926 cells. Data are expressed as the mean \pm standard error of three independent experiments $(\mathrm{n}=3)$, ${ }^{*} \mathrm{P}<0.05$ and ${ }^{* *} \mathrm{P}<0.01$. LPS, lipopolysaccharide; CA, chebulagic acid; JNK, c-Jun N-terminal kinase; ERK, extracellular signal-regulated kinase; ns, no significance.

A
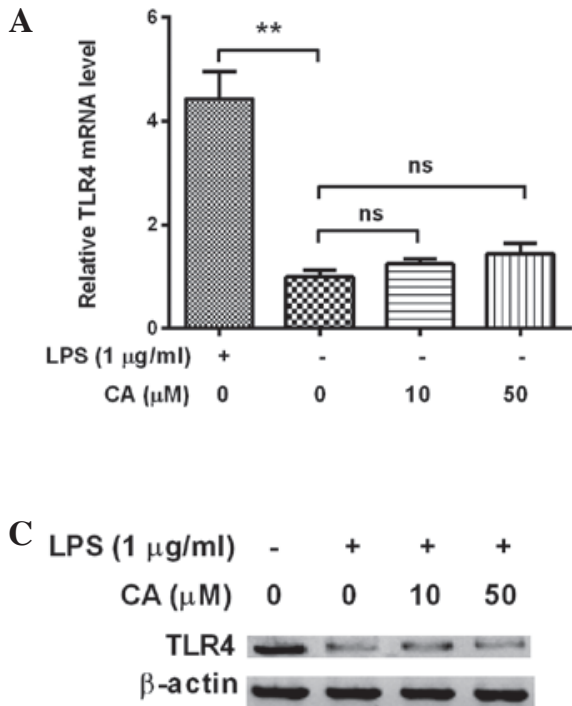

B
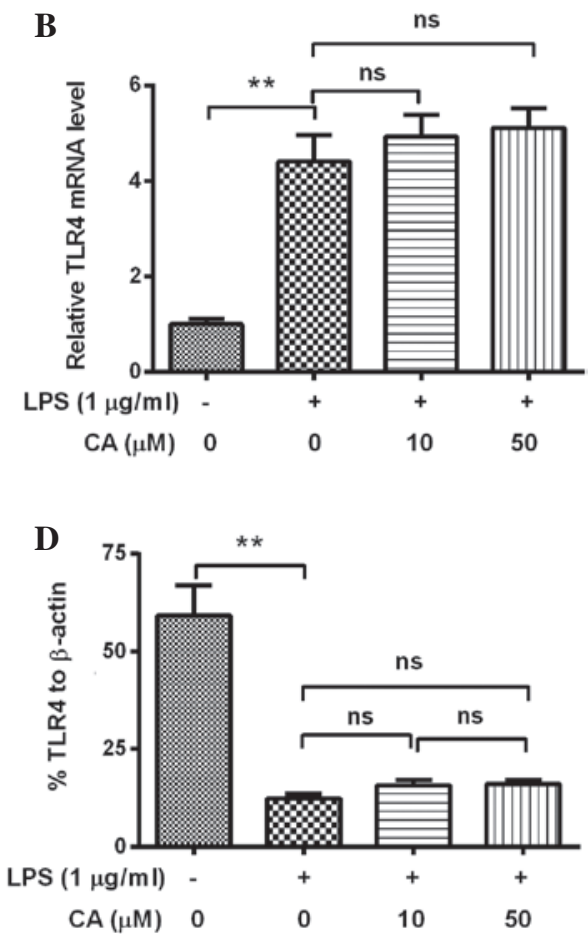

Figure 4. Effect of CA on the upregulation of TLR4 in LPS-stimulated EA.hy926 cells. (A) Relative TLR4 mRNA levels in EA.hy926 cells treated with $1 \mu \mathrm{g} / \mathrm{ml}$ LPS or CA $(10$ or $50 \mu \mathrm{M})$. (B) Relative TLR4 mRNA levels in EA.hy926 cells treated with a combination of $1 \mu \mathrm{g} / \mathrm{ml}$ LPS and 10 or $50 \mu \mathrm{M} \mathrm{CA}$. (C) Western blot analysis of TLR4 in EA.hy926 cells treated with a combination of $1 \mu \mathrm{g} / \mathrm{ml}$ LPS and 10 or $50 \mu \mathrm{M} \mathrm{CA}$. (D) Percentage of TLR4 to $\beta$-actin in the LPS and CA-treated EA.hy926 cells. All experiments were performed in triplicate. ${ }^{*} \mathrm{P}<0.01$. TLR4, toll-like receptor 4; LPS, lipopolysaccharide; CA, chebulagic acid; ns, no significance.

CA exerts no effect on the LPS-induced activation of TLR4 signaling in endothelial cells. TLRs, such as TLR4, are type-I transmembrane receptors expressed on the cell membrane following LPS stimulation (31). Activation of TLR4 signaling by LPS is associated with the release of LPS-induced inflammatory cytokines (32). In order to determine whether TLR4 signaling is targeted by CA to attenuate the LPS-induced release of inflammatory cytokines, the expression of TLR4 
mRNA and protein was determined in EA.hy926 cells treated with LPS and/or CA. As shown in Fig. 4A, the mRNA expression levels of TLR4 were significantly upregulated by LPS treatment $(\mathrm{P}=0.003)$; however, treatment with 10 or $50 \mu \mathrm{M}$ CA alone exerted no upregulatory effect on TLR4 mRNA $(\mathrm{P}=0.177$ and 0.140 , respectively). Furthermore, experiments in which combined treatments were applied indicated that treatment with 10 or $50 \mu \mathrm{M}$ CA did not exert a significant effect on the LPS-induced promotion of TLR4 mRNA levels $(\mathrm{P}=0.511$ or 0.366 ; Fig. 4B). Western blot analysis indicated that no CA-mediated regulation of TLR4 expression occurred at the protein level in EA.hy926 cells, as no significant difference in TLR4 expression levels was observed between the cells treated with LPS alone and those treated with a combination of LPS and CA (Fig. 4C and D).

\section{Discussion}

Endothelial inflammation has been implicated in a variety of diseases, including infection (33), diabetes (34), atherosclerosis (35) and hypertension (36). Furthermore, endothelial inflammation is commonly associated with thrombosis $(37,38)$. Various factors promote endothelial cells to an inflammation-activated status and induce them to secrete proinflammatory cytokines. Oncogenes and oxidative stress induce vascular endothelial cells to exhibit distinct expression patterns of proinflammatory cytokines (39). In newly diagnosed type 2 diabetes, levels of serum IL-12 correlate with endothelial dysfunction, insulin resistance and the expression of proinflammatory cytokines (40). Exposure to Shiga toxin 1, Shiga toxin 2 , and $\alpha$-sarcin induces molecular damage and upregulates proinflammatory cytokines in human endothelial cells (41). Furthermore, classical swine fever virus has been found to induce proinflammatory cytokine and tissue factor expression during the establishment of long-term infection in porcine vascular endothelial cells (42). In addition, bacterial LPS modulates inflammasome gene expression and regulates IL-1 $\beta$ and TNF- $\alpha$ secretion in endothelial cells $(43,44)$. Considering the high level of association of proinflammatory cytokines, such as IL-1 $\beta$ and TNF- $\alpha$, with thrombosis, anti-inflammatory activity in the vasculature may be a response strategy for the prevention or control of thrombosis.

The present study demonstrated the anti-inflammatory effects of CA in endothelial cells. CA was demonstrated to inhibit the LPS-induced secretion of two key proinflammatory cytokines, IL-1 $\beta$ and TNF- $\alpha$, in EA.hy926 endothelial cells. The LPS-induced promotion of IL-1 $\beta$ and TNF- $\alpha$ in the EA.hy926 cells was significantly attenuated by CA in a doseand time-dependent manner. Furthermore, it was observed that the CA inhibited LPS-induced activation of MAPK signaling $(29,30)$ in endothelial cells. Western blot analysis demonstrated that the LPS treatment promoted the phosphorylation of p38, JNK and ERK in EA.hy926 cells. This promotion was inhibited by CA treatment, with the phosphorylation of p38, JNK and ERK significantly attenuated by treatment with $\geq 10 \mu \mathrm{M} \mathrm{CA}$, in a dose-dependent manner.

TLRs, such as TLR4, are type-I transmembrane receptors expressed on the cell membrane following LPS stimulation (31). Activation of TLR4 signaling by LPS is associated with the release of inflammatory cytokines (32). However, no regulatory effect of CA on TLR4 expression, which was upregulated by LPS during its promotion of inflammatory cytokine release in EA.hy926 endothelial cells, was observed. The RT-qPCR and western blot analyses respectively revealed the upregulated mRNA and protein levels of TLR4 by LPS in EA.hy926 cells were not significantly attenuated by treatment with 10-50 $\mu \mathrm{M} \mathrm{CA}$. Therefore, it is hypothesized that the regulation of IL- $1 \beta$ and TNF- $\alpha$ is targeted post TLR4 signaling. However, the specific targets for CA remain unclear and require identification.

In summary, the present study demonstrated that CA inhibited LPS-induced vascular inflammation in EA.hy926 human endothelial cells via the suppression of MAPK activation.

\section{Acknowledgements}

This study was supported by a grant from the Inner Mongolia Science Foundation (no. 2012ms1211).

\section{References}

1. Richardson MW, Allen GA and Monahan PE: Thrombosis in children: Current perspective and distinct challenges. Thromb Haemost 88: 900-911, 2002.

2. Gurgey A and Aslan D: Outcome of noncatheter-related thrombosis in children: Influence of underlying or coexisting factors. J Pediatr Hematol Oncol 23: 159-164, 2001.

3. Becarevic M, Ignjatovic S and Majkic-Singh N: Deterioration of thromboses in primary antiphospholipid syndrome: TNF-alpha and anti-annexin A5 antibodies. Clin Lab 58: 1079-1084, 2012.

4. Schafer A, Schulz C, Eigenthaler M, et al: Novel role of the membrane-bound chemokine fractalkine in platelet activation and adhesion. Blood 103: 407-412, 2004.

5. Raab M, Daxecker H, Markovic S, Karimi A, Griesmacher A and Mueller MM: Variation of adhesion molecule expression on human umbilical vein endothelial cells upon multiple cytokine application. Clin Chim Acta 321: 11-16, 2002.

6. Clemetson KJ, Clemetson JM, Proudfoot AE, Power CA, Baggiolini $\mathrm{M}$ and Wells TN: Functional expression of CCR1, CCR3, CCR4 and CXCR4 chemokine receptors on human platelets. Blood 96: 4046-4054, 2000.

7. Bevilacqua MP, Pober JS, Majeau GR, Cotran RS and Gimbrone MJ: Interleukin 1 (IL-1) induces biosynthesis and cell surface expression of procoagulant activity in human vascular endothelial cells. J Exp Med 160: 618-623, 1984.

8. Conway EM, Bach R, Rosenberg RD and Konigsberg WH: Tumor necrosis factor enhances expression of tissue factor mRNA in endothelial cells. Thromb Res 53: 231-241, 1989.

9. Parry GC and Mackman N: Transcriptional regulation of tissue factor expression in human endothelial cells. Arterioscler Thromb Vasc Biol 15: 612-621, 1995.

10. Joseph L, Fink LM and Hauer-Jensen M: Cytokines in coagulation and thrombosis: A preclinical and clinical review. Blood Coagul Fibrinolysis 13: 105-116, 2002.

11. Mantovani A, Sozzani S, Vecchi A, Introna M and Allavena P: Cytokine activation of endothelial cells: New molecules for an old paradigm. Thromb Haemost 78: 406-414, 1997.

12. Esmon CT: Inflammation and thrombosis. J Thromb Haemost 1: 1343-1348, 2003.

13. Tapper $\mathrm{H}$ and Herwald $\mathrm{H}$ : Modulation of hemostatic mechanisms in bacterial infectious diseases. Blood 96: 2329-2337, 2000.

14. Bernardo A, Ball C, Nolasco L, Moake JF and Dong JF: Effects of inflammatory cytokines on the release and cleavage of the endothelial cell-derived ultralarge von Willebrand factor multimers under flow. Blood 104: 100-106, 2004.

15. Smadja D, Gaussem P, Roncal C, Fischer AM, Emmerich J and Darnige L: Arterial and venous thrombosis is associated with different angiogenic cytokine patterns in patients with antiphospholipid syndrome. Lupus 19: 837-843, 2010.

16. Kowalska MA, Rauova L and Poncz M: Role of the platelet chemokine platelet factor 4 (PF4) in hemostasis and thrombosis. Thromb Res 125: 292-296, 2010. 
17. Han Q, Song J, Qiao C, Wong L and Xu H: Preparative isolation of hydrolysable tannins chebulagic acid and chebulinic acid from Terminalia chebula by high-speed counter-current chromatography. J Sep Sci 29: 1653-1657, 2006.

18. Lin LT, Chen TY, Chung CY, et al: Hydrolyzable tannins (chebulagic acid and punicalagin) target viral glycoprotein-glycosaminoglycan interactions to inhibit herpes simplex virus 1 entry and cell-to-cell spread. J Virol 85: 4386-4398, 2011.

19. Gyorkey F, Melnick JL, Guinn GA, Gyorkey P and DeBakey ME: Herpesviridae in the endothelial and smooth muscle cells of the proximal aorta in arteriosclerotic patients. Exp Mol Pathol 40: 328-339, 1984

20. Melnick JL, Petrie BL, Dreesman GR, Burek J, McCollum CH and DeBakey ME: Cytomegalovirus antigen within human arterial smooth muscle cells. Lancet 2: 644-647, 1983.

21. Hajjar DP, Pomerantz KB, Falcone DJ, Weksler BB and Grant AJ: Herpes simplex virus infection in human arterial cells Implications in arteriosclerosis. J Clin Invest 80: 1317-1321, 1987.

22. Visser MR, Tracy PB, Vercellotti GM, Goodman JL, White JG and Jacob HS: Enhanced thrombin generation and platelet binding on herpes simplex virus-infected endothelium. Proc Nat Acad Sci USA 85: 8227-8230, 1988

23. Yu Y, Ricciotti E, Scalia R, et al: Vascular COX-2 modulates blood pressure and thrombosis in mice. Sci Transl Med 4 $132 \mathrm{r}-154 \mathrm{r}, 2012$

24. Armstrong PC, Kirkby NS, Zain ZN, Emerson M, Mitchell JA and Warner TD: Thrombosis is reduced by inhibition of COX-1, but unaffected by inhibition of COX-2, in an acute model of platelet activation in the mouse. PLoS One 6: e20062, 2011.

25. de Gaetano G, Donati MB and Cerletti C: Prevention of thrombosis and vascular inflammation: Benefits and limitations of selective or combined COX-1, COX-2 and 5-LOX inhibitors. Trends Pharmacol Sci 24: 245-252, 2003.

26. Umar A, Boisseau M, Yusup A, Upur H, Begaud B and Moore N: Interactions between aspirin and COX-2 inhibitors or NSAIDs in a rat thrombosis model. Fundam Clin Pharmacol 18: 559-563, 2004.

27. Reddy DB and Reddanna P: Chebulagic acid (CA) attenuates LPS-induced inflammation by suppressing NF-kappaB and MAPK activation in RAW 264.7 macrophages. Biochem Biophys Res Commun 381: 112-117, 2009.

28. Livak KJ and Schmittgen TD: Analysis of relative gene expression data using real-time quantitative PCR and the 2(-Delta Delta C(T)) method. Methods 25: 402-408, 2001.

29. Kirchner S, Boldt S, Kolch W, et al: LPS resistance in monocytic cells caused by reverse signaling through transmembrane TNF (mTNF) is mediated by the MAPK/ERK pathway. J Leukoc Biol 75: 324-331, 2004.

30. Kang JS, Kim HM, Choi IY, et al: DBM1285 suppresses tumor necrosis factor alpha production by blocking p38 mitogen-activated protein kinase/mitogen-activated protein kinase-activated protein kinase 2 signaling pathway. J Pharmacol Exp Ther 334: 657-664, 2010.
31. Medvedev AE, Lentschat A, Wahl LM, Golenbock DT and Vogel SN: Dysregulation of LPS-induced Toll-like receptor 4-MyD88 complex formation and IL-1 receptor-associated kinase 1 activation in endotoxin-tolerant cells. J Immunol 169: 5209-5216, 2002.

32. Levy O: Innate immunity of the human newborn: Distinct cytokine responses to LPS and other toll-like receptor agonists. J Endotoxin Res 11: 113-116, 2005.

33. Schouten M, Wiersinga WJ, Levi $M$ and van der Poll T: Inflammation, endothelium and coagulation in sepsis. J Leukoc Biol 83: 536-545, 2008

34. Hartge MM, Unger T and Kintscher U: The endothelium and vascular inflammation in diabetes. Diab Vasc Dis Res 4: 84-88, 2007.

35. Libby P, Ridker PM and Maseri A: Inflammation and atherosclerosis. Circulation 105: 1135-1143, 2002.

36. Rojas E, Rodriguez-Molina D, Bolli P, et al: The role of adiponectin in endothelial dysfunction and hypertension. Curr Hypertens Rep 16: 463, 2014.

37. Hirahashi J, Hishikawa K, Kaname S, et al: Mac-1 (CD11b/CD18) links inflammation and thrombosis after glomerular injury. Circulation 120: 1255-1265, 2009.

38. Contreras JL, Eckstein C, Smyth CA, et al: Activated protein C preserves functional islet mass after intraportal transplantation: A novel link between endothelial cell activation, thrombosis, inflammation and islet cell death. Diabetes 53: 2804-2814, 2004.

39. Suzuki E, Takahashi M, Oba S and Nishimatsu H: Oncogeneand oxidative stress-induced cellular senescence shows distinct expression patterns of proinflammatory cytokines in vascular endothelial cells. Scientific World Journal 2013: 754735, 2013.

40. Mishra M, Kumar H, Bajpai S, Singh RK and Tripathi K: Level of serum IL-12 and its correlation with endothelial dysfunction, insulin resistance, proinflammatory cytokines and lipid profile in newly diagnosed type 2 diabetes. Diabetes Res Clin Pract 94: 255-261, 2011.

41. Brigotti M, Carnicelli D, Ravanelli E, et al: Molecular damage and induction of proinflammatory cy tokines in human endothelial cells exposed to Shiga toxin 1, Shiga toxin 2 and alpha-sarcin. Infect Immun 75: 2201-2207, 2007.

42. Bensaude E, Turner JL, Wakeley PR, et al: Classical swine fever virus induces proinflammatory cytokines and tissue factor expression and inhibits apoptosis and interferon synthesis during the establishment of long-term infection of porcine vascular endothelial cells. J Gen Virol 85: 1029-1037, 2004.

43. Pontillo A, Girardelli M, Agostinis C, Masat E, Bulla R and Crovella S: Bacterial LPS differently modulates inflammasome gene expression and IL-1beta secretion in trophoblast cells, decidual stromal cells and decidual endothelial cells. Reprod Sci 20: 563-566, 2013

44. Hu Y, Chen X, Duan H, Hu Y and Mu X: Pulsatilla decoction and its active ingredients inhibit secretion of NO, ET-1, TNF-alpha and IL-1 alpha in LPS-induced rat intestinal microvascular endothelial cells. Cell Biochem Funct 27: 284-288, 2009. 